Research Paper

\title{
Reproductive factors as risk modifiers of breast cancer in BRCA mutation carriers and high-risk non-carriers
}

\author{
Boyoung Park1,2, John L. Hopper ${ }^{3}$, Aung K. Win ${ }^{3}$, James G. Dowty ${ }^{3}$, Ho Kyung \\ Sung ${ }^{4,5}$, Choonghyun Ahn ${ }^{4,5,6}$, Sung-Won Kim, Min Hyuk Lee ${ }^{8}$, Jihyoun Lee ${ }^{8}$, Jong \\ Won Lee ${ }^{9}$, Eunyoung Kang ${ }^{10}$, Jong-Han $\mathrm{Yu}^{11}$, Ku Sang Kim ${ }^{12}$, Byung-In Moon ${ }^{13}$, \\ Wonshik Han ${ }^{14}$, Dong-Young Noh ${ }^{14}$ Sue K. Park ${ }^{4,5,6}$ and KOHBRA Study Group \\ ${ }^{1}$ Department of Cancer Control and Population Health, National Cancer Center Graduate School of Cancer Science and Policy, \\ Gyeonggi-Do, Korea \\ ${ }^{2}$ National Cancer Control Institute, National Cancer Center, Gyeonggi-Do, Korea \\ ${ }^{3}$ Centre for Epidemiology and Biostatistics, Melbourne School of Population and Global Health, The University of Melbourne, \\ Parkville, Victoria, Australia \\ ${ }^{4}$ Department of Preventive Medicine, Seoul National University College of Medicine, Seoul, Korea \\ ${ }^{5}$ Cancer Research Institute, Seoul National University, Seoul, Korea \\ ${ }^{6}$ Department of Biomedical Science, Seoul National University Graduate School, Seoul, Korea \\ ${ }^{7}$ Department of Surgery, Daerim-Sungmo Hospital, Seoul, Korea \\ ${ }^{8}$ Department of Surgery, College of Medicine, Soonchunhyang University, Seoul, Korea \\ ${ }^{9}$ Department of Surgery, College of Medicine, University of Ulsan and Asan Medical Center, Seoul, Korea \\ ${ }^{10}$ Department of Surgery, Breast and Endocrine Service, Seoul National University Bundang Hospital, Gyeonggi-Do, Korea \\ ${ }^{11}$ Division of Breast and Endocrine Surgery, Department of Surgery, Samsung Medical Center, Sungkyunkwan University \\ School of Medicine, Seoul, Korea \\ ${ }^{12}$ Breast-Thyroid Center, Ulsan City Hospital, Ulsan City Hospital Group, Ulsan, Korea \\ ${ }^{13}$ Department of Surgery, Ewha Womans University Hospital, Seoul, Korea \\ ${ }^{14}$ Department of Surgery, Seoul National University College of Medicine, Seoul, Korea \\ Correspondence to: Sue K. Park, email: suepark@snu.ac.kr \\ Keywords: breast neoplasm; reproductive factors; BRCA $1 / 2$ mutation carriers; familial breast cancer; early onset breast cancer \\ Received: June 20,2017 Accepted: September 21, $2017 \quad$ Published: October 31, 2017 \\ Copyright: Park et al. This is an open-access article distributed under the terms of the Creative Commons Attribution License 3.0 \\ (CC BY 3.0), which permits unrestricted use, distribution, and reproduction in any medium, provided the original author and source \\ are credited.
}

\section{ABSTRACT}

This study was conducted to identify the role of reproductive factors as environmental modifiers for breast cancer (BC) risk in clinic-based, East-Asian BRCA1 and $B R C A 2$ mutation carriers and non-carriers with high-risk criteria of $B R C A$ mutations (family history ( $F H$ ) of BC, early-onset BC (aged $\leq 40$ years)). A total of 581 women who were BRCA carriers ( 222 BRCA1 and 359 BRCA2), 1,083 non-carriers with $\mathrm{FH}$, and 886 non-carriers with early-onset $B C$ were enrolled and interviewed to examine the reproductive factors, from 2007 to 2014 . The hazard ratio (HR) and its $95 \%$ confidence interval (CI) in the weighted Cox regression model were used to calculate the $\mathrm{BC}$ risk based on the reproductive factors. Earlier menarche increased BC risk by 3.49-fold in BRCA2 mutation carriers $(95 \% \mathrm{CI}=2.03-6.00)$ and 3.30 -fold in non-carriers with FH $(95 \% \mathrm{CI}=1.73-6.34)$, but was insignificantly associated with BRCA1 carriers and non-carriers for early-onset $B C(P-h e t e r o g e n e i t y=0.047)$. Higher parity decreased $B C$ risk in BRCA carriers and non-carriers with $\mathrm{FH}$, especially in $B R C A 1$ carriers $(H R=0.27$, 95\% CI=0.09-0.83 for two parity; and $\mathrm{HR}=0.23,95 \% \mathrm{CI}=0.05-1.00$ for $\geq 3$ parity), but increased the early-onset $B C$ risk $(H R=4.63,95 \% C I=2.56-8.51$ for $>3$ parity, 


\begin{abstract}
p-heterogeneity $=0.045)$. Oral contraceptive $(O C)$ use and longer estrogen exposure periods ( $\geq 30$ years) were associated with an increased risk of early-onset BC (HR=3.99, 95\% $\mathrm{CI}=1.65-9.67 ; \mathrm{HR}=7.69,95 \% \mathrm{CI}=1.96-25.01$ ), while $\mathrm{OC}$ use was not associated with BC risk in other groups and longer estrogen exposure had rather decreased risk for $\mathrm{BC}$ risk (both p-heterogeneity<0.001). Several reproductive factors as risk modifiers could heterogeneously be associated with $\mathrm{BC}$ among BRCA1/2 mutation carriers, noncarriers with FH, and early-onset BC non-carriers.
\end{abstract}

\section{INTRODUCTION}

Germline mutations in the BRCA1 or BRCA2 genes are responsible for about $5 \%$ of breast cancer $(\mathrm{BC})$ and are associated with a substantially increased lifetime risk of BC to 70 years old with approximately $65 \%$ and $45 \%$ of risk, respectively, in Caucasian populations [1,2].

Reproductive factors, including lower number of parity, late parity, early age at menarche, and late menopausal age, are well-established risk factors of female $\mathrm{BC}$ in the general population [3, 4]. However, whether reproductive factors in the general population would act as risk factors for $\mathrm{BC}$ in $B R C A 1 / 2$ mutation carriers remain questionable, because $B R C A 1 / 2$ mutation can disrupt the estrogenic response in tissues by mutation itself [5] or an interaction with many other genes $[6,7]$. Previous studies of $\mathrm{BC}$ risk based on the reproductive factors in $B R C A 1 / 2$ mutation carriers have produced inconsistent results; hence, the question remains [8-17]. Thus, the direction in the association of reproductive factors on $\mathrm{BC}$ risk in the general population has been hypothesized to be somewhat different from that in mutation carriers and genetically high-risk groups, such as familial $\mathrm{BC}$ or early-onset BC patients.

In particular, Asians have different BC-related characteristics from the Westerners. For example, Asians have a different distribution of genetic and environmental risk factors, such as lower incidence of $\mathrm{BC}$ and mortality rates, different age-specific incidence rate, poor prediction of $\mathrm{BC}$ assessment models developed in the Western populations, and higher prevalence of $B R C A 2$ than $B R C A 1$ mutations [18-20]. Therefore, identifying whether the effects of reproductive factors as risk modifiers of $\mathrm{BC}$ in $B R C A$ mutation carriers are similar or not is necessary, regardless of ethnic differences. To date, few studies have focused on the effects of reproductive factors on $\mathrm{BC}$ for $B R C A 1 / 2$ mutation carriers in East-Asian population. The effect of reproductive factors on $\mathrm{BC}$ risk in the general population may be also different from that in genetically high-risk groups, such as familial $\mathrm{BC}$ or early-onset $\mathrm{BC}$; however, previous studies on $\mathrm{BC}$ with family history $(\mathrm{FH})$ or early-onset $\mathrm{BC}$ did not exist.

Thus, this study aimed to investigate the role of reproductive factors as risk modifiers of $\mathrm{BC}$ in $B R C A 1 / 2$ mutation carriers and hereditary high-risk groups without $B R C A 1 / 2$ mutations, such as non-carriers with $\mathrm{FH}$ of $\mathrm{BC}$ and non-carriers with early-onset $\mathrm{BC}$ in an East-Asian population.
RESULTS

Table 1 shows the characteristics of female participants included in this study among the Korean Hereditary BC (KOHBRA) study. The BC patients with $B R C A 2$ mutation, non-carriers with $\mathrm{FH}$ of $\mathrm{BC}$, and noncarriers with early-onset $\mathrm{BC}$ were older than the controls. The proportion of postmenopausal women was higher in $B R C A 2$ carrier $\mathrm{BC}$ patients than $B R C A 2$ carrier controls $(P<0.05)$. In all groups, the proportion of current drinkers was lower in $\mathrm{BC}$ patients than controls $(P<0.05)$.

Tables 2 and 3 show the associations between reproductive factors and $\mathrm{BC}$ risk in $B R C A 1 / 2$ mutation carriers, non-carriers with $\mathrm{FH}$ of $\mathrm{BC}$, and non-carriers with early-onset BC. Increased number of parity was significantly associated with reduced risk of $\mathrm{BC}$ in $B R C A 1$ mutation carriers (hazard ratio $(\mathrm{HR})=0.27$, $95 \%$ confidence interval $(\mathrm{CI})=0.09-0.83$ for two parity; $\mathrm{HR}=0.23,95 \% \mathrm{CI}=0.05-1.00$ for $\geq 3$ parity; $\mathrm{p}$-trend $<0.001$ ) and increased risk for the early-onset $\mathrm{BC}$ in noncarriers ( $\mathrm{HR}=4.63,95 \% \mathrm{CI}=2.56-8.51$ for $\geq 3$ parity). The associations among the four groups were statistically heterogeneous (P-heterogeneity $<0.001$ ). For women $\leq 40$ years old, later age at first full-term pregnancy (FFTP) decreased the $\mathrm{BC}$ risk in BRCA1 mutation carriers ( $\mathrm{HR}=0.33,95 \% \mathrm{CI}=0.12-0.90$ for $24-29$ years old at FFTP; HR $=0.14,95 \%$ CI $=0.03-0.66$ for $\geq 30$ years old at FFTP, compared with women aged $\leq 23$ years at FFTP; p-trend $<0.001)$. However, for women $>40$ years old, with FFTP between 24 and 29 years old, increased BC risk was observed in BRCA2 mutation carriers compared with $B R C A 2$ mutation carriers whose age at FFTP was $\leq 23$ years old $(\mathrm{HR}=3.24,95 \% \mathrm{CI}=1.43-7.40)$. In addition, a significant trend between later age at FFTP and BC risk in BRCA1 mutation carriers was also observed ( $p$-trend $=0.01$ ). Oral contraceptive (OC) use had a 4.29-fold higher risk for early-onset $\mathrm{BC}$ in non-carriers $(95 \% \mathrm{CI}, 2.17-$ 9.34), but was not associated with $\mathrm{BC}$ risk in other groups $(\mathrm{P}$-heterogeneity among four groups $=0.045)$.

Earlier menarche ( $\leq 14$ years old) increased the $\mathrm{BC}$ risk by 3.49 -fold in $B R C A 2$ mutation carriers $(95 \%$ $\mathrm{CI}=2.03-6.00)$ and 3.30-fold in non-carriers with $\mathrm{FH}$ of $\mathrm{BC}(95 \% \mathrm{CI}=1.73-6.34)$, but was insignificantly associated with $\mathrm{BC}$ in BRCA1 carriers and early-onset $B C$ non-carriers (P-heterogeneity $=0.047)$. Premenopausal $B R C A 1$ mutation carriers showed an increased risk for $\mathrm{BC}$ compared with $B R C A 1$ mutation carriers with menopausal age at $<44$ years old $(\mathrm{HR}=2.27 ; 95 \% \mathrm{CI}$, 
Table 1: Characteristics of female study participants with BRCA 1/2 mutation carriers, non-carriers with family history of breast cancer, and non-carriers with early-onset breast cancer

\begin{tabular}{|c|c|c|c|c|c|c|c|c|}
\hline & \multicolumn{2}{|c|}{$\begin{array}{l}\text { BRCA1 mutation } \\
\text { carriers }\end{array}$} & \multicolumn{2}{|c|}{$\begin{array}{l}B R C A 2 \text { mutation } \\
\text { carriers }\end{array}$} & \multicolumn{2}{|c|}{$\begin{array}{l}\text { Non-carriers with family } \\
\text { history of breast cancer }\end{array}$} & \multicolumn{2}{|c|}{$\begin{array}{l}\text { Non-carriers with early } \\
\text { onset breast cancer }\end{array}$} \\
\hline & $\begin{array}{l}\text { Breast } \\
\text { cancer }\end{array}$ & Control & $\begin{array}{l}\text { Breast } \\
\text { cancer }\end{array}$ & Control & $\begin{array}{l}\text { Breast } \\
\text { cancer }\end{array}$ & Control & $\begin{array}{l}\text { Breast } \\
\text { cancer }\end{array}$ & Control \\
\hline \multirow{3}{*}{ Age at participation ${ }^{1}$} & Mean (SD) & Mean (SD) & Mean (SD) & Mean (SD) & Mean (SD) & Mean (SD) & Mean (SD) & Mean (SD) \\
\hline & $40.2(8.1)$ & $39.5(13.7)$ & $46.3(11.1)^{2}$ & $38.8(13.1)^{2}$ & $46.2(9.8)^{2}$ & $41.7(14.1)^{2}$ & $35.2(5.4)^{2}$ & $29.7(5.8)^{2}$ \\
\hline & N (\%) & N (\%) & N (\%) & N (\%) & N (\%) & N (\%) & N (\%) & N (\%) \\
\hline $\begin{array}{l}\text { Postmenopausal } \\
\text { women }\end{array}$ & $40(23.8)$ & $13(24.1)$ & $112(44.8)^{2}$ & $19(17.4)^{2}$ & $303(35.4)$ & $46(25.6)$ & $54(7.0)$ & $1(1.1)$ \\
\hline Current drinkers & $32(19.1)^{2}$ & $17(31.5)^{2}$ & $42(16.8)^{2}$ & $45(41.3)^{2}$ & $132(15.4)^{2}$ & $87(48.3)^{2}$ & $157(20.3)^{2}$ & $56(63.6)^{2}$ \\
\hline Current smokers & $7(4.2)$ & $5(9.3)$ & $4(1.6)$ & $2(1.8)$ & $26(3.0)$ & $6(3.3)$ & $17(2.2)$ & $6(6.8)$ \\
\hline $\mathrm{BMI} \geq 25 \mathrm{Kg} / \mathrm{m}^{2}$ & $28(16.8)$ & $8(14.8)$ & $46(18.4)$ & $23(21.1)$ & $172(20.1)$ & $32(17.8)$ & $108(14.0)$ & $9(10.2)$ \\
\hline
\end{tabular}

BMI body mass index, BC breast cancer, OC ovarian cancer, SD standard deviation, $\mathrm{N}$ number

${ }^{1}$ Age at diagnosis in breast cancer patients; Age at enrollment in controls ${ }^{2} \mathrm{p}<0.05$

1.02-5.88); however, no association was observed in other groups (p-heterogeneity $<0.001$ ). Increased age at menopause was associated with decreased risk for $\mathrm{BC}$, especially in BRCA1 mutation carriers and non-carriers with $\mathrm{FH}$ of $\mathrm{BC}$ (for menopausal women at $\geq 50$ years old, $\mathrm{HR}=0.13,95 \% \mathrm{CI}=0.04-0.51 ; \mathrm{HR}=0.17,05 \% \mathrm{CI}=0.05$ 0.61 ; P-trend $<0.001$ and 0.02 ). Longer estrogen exposure periods (LEEP, $\geq 30$ years) were associated with higher risk for early-onset $\mathrm{BC}$ in non-carriers $(\mathrm{HR}=7.69$; $95 \%$ $\mathrm{CI}, 1.96-25.01)$, but rather decreased risk for $\mathrm{BC}$ risk in other groups (P-heterogeneity $<0.001$ ). Figure 1 presents the association trends between age at menarche, OC use, number of parity, estrogen exposure period, and $\mathrm{BC}$ risk.

\section{DISCUSSION}

We evaluated the association between reproductive factors as environmental risk modifiers and $\mathrm{BC}$ risk in the hereditary highly susceptible women, such as $B R C A 1 / 2$ mutation carriers and $B R C A 1 / 2$ mutation unrelated to high-risk females such as non-carriers with $\mathrm{FH}$ of $\mathrm{BC}$ and with early-onset BC.

Earlier menarche increased the risk of $\mathrm{BC}$ in $B R C A 2$ mutation carriers and non-carriers with $\mathrm{FH}$ of $\mathrm{BC}$ by threefold, but not in other two groups $(\mathrm{HR} \approx 1)$. Higher number of parity decreased $\mathrm{BC}$ risk by $80 \%$ in $B R C A 1$ mutation carriers, but rather increased the risk for earlyonset $\mathrm{BC}$ in non-carriers by approximately fourfold. OC use was associated with increased risk for only earlyonset $\mathrm{BC}$ in non-carriers by fourfold. LEEP and later age at menopause decreased $\mathrm{BC}$ risk in $B R C A 1 / 2$ mutation carriers and non-carriers with $\mathrm{FH}$, whereas LEEP rather increased the risk for early-onset BC. Later age at FFTP among women aged $\leq 40$ years was associated with decreased $\mathrm{BC}$ risk in BRCA1 mutation carriers, while showing an insignificantly increased association with the other three groups.

In this study, the number of parity and $\mathrm{BC}$ risk was inversely associated not only in BRCA1/2 mutation carriers but also in non-carriers with FH. However, this association was not observed in early-onset $\mathrm{BC}$ who were non-carriers, and rather the risk of early-onset $\mathrm{BC}$ was increased. Several epidemiological studies have reported that the risk of $\mathrm{BC}$ increases when young women give birth more than three times, which is consistent with our findings of early-onset BC [21, 22]. Excessive hormone levels from pregnancy and childbirth can promote malignant-transformed cell growth. This process can temporarily increase the risk of $\mathrm{BC}$ and then return to its original level with decreased hormone levels [23, 24]. More than three repetitive pregnancies and births in a very short period, especially at younger ages, may promote recurrent cumulative cell growth and thus increase the risk of $\mathrm{BC}$.

Previous reports regarding the age at FFTP and $\mathrm{BC}$ risk among $B R C A 1 / 2$ mutation carriers were inconsistent. Some studies showed that a later age at FFTP increased the $\mathrm{BC}$ risk in $B R C A 1 / 2$ [15] or $B R C A 2$ mutation carriers $[8,9]$; other studies showed no association $[13,14,25]$ or decreased risk in BRCA1 mutation carriers [8]. The inconsistency among studies might be due to the age of $\mathrm{BC}$ occurrence, which alters the pregnancy history, or differences in the statistical power based on the limited number of $B R C A 1 / 2$ mutation carriers included in the studies. In the general population, pregnancy increased the risk of $\mathrm{BC}$ in the short term, followed by a long-term risk reduction, with an effect of pregnancy on decreased $\mathrm{BC}$ risk among women $>40$ years old. This is explained by exposure to high hormonal concentrations during pregnancy, which increases the growth of preclinical 
Table 2: Number of parity, age at first full-term pregnancy, and oral contraceptive use for the risk of breast cancer in $B R C A$ 1/2 mutation carriers, non-carriers with family history of breast cancer, and non-carriers with early-onset breast cancer

\begin{tabular}{|c|c|c|c|c|c|c|c|c|}
\hline & \multicolumn{2}{|c|}{ BRCA1 mutation carriers } & \multicolumn{2}{|c|}{$B R C A 2$ mutation carriers } & \multicolumn{2}{|c|}{$\begin{array}{l}\text { Non-carriers with family } \\
\text { history of breast cancer }\end{array}$} & \multicolumn{2}{|c|}{$\begin{array}{l}\text { Non-carriers with early- } \\
\text { onset breast cancer }\end{array}$} \\
\hline & Cohort N & HR $(95 \% \text { CI })^{1}$ & Cohort N & $\operatorname{HR}(95 \% \mathrm{CI})^{1}$ & Cohort N & $\operatorname{HR}(95 \% \mathrm{CI})^{1}$ & Cohort N & $\operatorname{HR}(95 \% \mathrm{CI})^{1}$ \\
\hline \multicolumn{9}{|c|}{ Number of parity } \\
\hline 0 & 44 & $2.13(0.65-6.56)$ & 61 & $1.12(0.27-4.60)$ & 162 & $1.49(0.50-4.85)$ & 274 & $2.13(0.60-7.67)$ \\
\hline 1 & 78 & 1 & 142 & 1 & 303 & 1 & 292 & 1 \\
\hline 2 & 79 & $0.27(0.09-0.83)$ & 113 & $0.48(0.21-1.06)$ & 474 & $1.03(0.50-2.13)$ & 277 & $0.45(0.21-0.92)$ \\
\hline $3 \leq$ & 21 & $0.23(0.05-1.00)^{2}$ & 43 & $0.46(0.13-1.33)^{2}$ & 143 & $0.52(0.24-1.13)^{2}$ & 43 & $4.63(2.56-8.51)^{2}$ \\
\hline $\mathrm{p}$-trend & & $<0.001$ & & 0.05 & & 0.02 & & 0.50 \\
\hline \multicolumn{9}{|l|}{ Age at FFTP } \\
\hline \multicolumn{9}{|c|}{ Women $\leq$ attained age 40} \\
\hline$\leq 23$ years & 20 & 1 & 27 & 1 & 90 & 1 & 82 & 1 \\
\hline $24-29$ & 54 & $0.33(0.12-0.90)$ & 68 & $1.23(0.33-4.56)$ & 148 & $\begin{array}{l}2.53(0.56- \\
11.38)\end{array}$ & 400 & $1.21(0.27-5.61)$ \\
\hline $30 \leq$ & 22 & $0.14(0.03-0.66)$ & 38 & $1.14(0.25-5.28)$ & 91 & $1.38(0.29-6.59)$ & 126 & $\begin{array}{l}2.68(0.48- \\
14.82)\end{array}$ \\
\hline $\mathrm{p}$-trend & & $<0.001$ & & 0.50 & & 0.40 & & 0.06 \\
\hline \multicolumn{9}{|c|}{ Women $>$ attained age 40} \\
\hline$\leq 23$ years & 12 & 1 & 46 & 1 & 132 & 1 & & \\
\hline $24-29$ & 47 & $1.98(0.91-4.31)$ & 90 & $3.24(1.43-7.40)$ & 350 & $0.96(0.49-1.89)$ & & NA \\
\hline $30 \leq$ & 15 & $1.99(0.63-6.24)$ & 24 & $1.52(0.33-7.17)$ & 97 & $0.62(0.19-2.01)$ & & \\
\hline $\mathrm{p}$-trend & & 0.01 & & 0.60 & & 0.10 & & \\
\hline \multicolumn{9}{|c|}{ Oral contraceptive use } \\
\hline Never & 189 & 1 & 314 & 1 & 967 & 1 & 780 & 1 \\
\hline Ever & 33 & $1.24(0.45-3.40)^{2}$ & 45 & $0.71(0.21-2.37)^{2}$ & 115 & $1.59(0.51-5.00)^{2}$ & 106 & $4.29(2.17-9.34)^{2}$ \\
\hline
\end{tabular}

N number, HR hazard ratio, CI confidence interval, FFTP first full-term pregnancy, NA not available

${ }^{1}$ Adjusted for all listed variables in the table, age at first full-term pregnancy, menopausal status, age at menopause, current drinking status, and birth cohort

${ }^{2}$ Statistically significant heterogeneity among HRs $(95 \%$ CIs) from 4 groups ( $p<0.001$ for $\geq 3$ parity; $p=0.045$ for ever oral contraceptive use)

tumors; however, pregnancy hormones can also reduce the susceptible cells in the breast by promoting differentiation [26]. According to this hypothesis, the analysis was stratified based on the attained age ( $\leq 40$ vs. $>40$ years) and identified decreased risk in $B R C A 1$ carriers aged $\leq 40$ years and increased risk in $B R C A 1 / 2$ carriers aged $>40$ years as the age at FFTP increased. Our finding that $\mathrm{OC}$ use increased the early-onset $\mathrm{BC}$ risk in non-carriers was consistent with that of a previous meta-analysis [27], suggesting that reproductive factors including endogenous and exogenous hormonal factors affected the early-onset cases more.

Results of studies associating menarche and $\mathrm{BC}$ risk in hereditary highly susceptible women were inconsistent. Previous Western meta-analyses [28, 29] and individual studies [12,17] have observed a correlation between earlier menarche and higher $\mathrm{BC}$ risk in $B R C A 1$ mutation carriers, whereas we observed these associations in $B R C A 2$ mutations or non-carriers with $\mathrm{FH}$. This result might be due to the difference in $B R C A 1 / 2$ mutation prevalence of the ethnic groups. The prevalence of $B R C A 1$ mutation is higher in Western populations; however, in Asian populations, $B R C A 2$ mutation prevalence is higher [20]. Therefore, risk modification effects of menarche may be observed only among mutation carriers with high prevalence. In non-carriers with $\mathrm{FH}$, the relationship between menarche and $\mathrm{BC}$ risk has not been reported. However, the observed association in this study would be biologically accountable. The age at menarche has familial trait and could be regulated by other susceptible genes besides $B R C A 1 / 2$ mutations and/or gene and environment interactions $[30,31]$.

The alleged risk factors in the general population such as later age at menopause and longer estrogen exposure were 
Table 3: Age at menarche, age at menopause, and estrogen exposure periods for the risk of breast cancer in BRCA 1/2 mutation carriers, non-carriers with family history of breast cancer, and non-carriers with early-onset breast cancer

\begin{tabular}{|c|c|c|c|c|c|c|c|c|}
\hline & \multicolumn{2}{|c|}{ BRCA1 mutation carriers } & \multicolumn{2}{|c|}{ BRCA2 mutation carriers } & \multicolumn{2}{|c|}{$\begin{array}{l}\text { Non-carriers with family } \\
\text { history of breast cancer }\end{array}$} & \multicolumn{2}{|c|}{$\begin{array}{c}\text { Non-carriers with early-onset } \\
\text { breast cancer }\end{array}$} \\
\hline & Cohort N & HR $(95 \% \text { CI })^{1}$ & Cohort N & $\operatorname{HR}(95 \% \mathrm{CI})^{1}$ & Cohort N & HR $(95 \% \text { CI })^{1}$ & Cohort N & HR $(95 \% \text { CI })^{1}$ \\
\hline \multicolumn{9}{|l|}{ Age at menarche } \\
\hline$\leq 14$ years $^{2}$ & 133 & $1.14(0.67-2.09)^{2}$ & 165 & $3.49(2.13-6.00)^{2}$ & 516 & $3.30(1.73-6.34)^{2}$ & 562 & $1.12(0.57-2.33)^{2}$ \\
\hline$\geq 15$ & 89 & 1 & 193 & 1 & 564 & 1 & 324 & 1 \\
\hline \multicolumn{9}{|l|}{ Age at menopause } \\
\hline Premenopause $^{2}$ & 162 & $2.27(1.02-5.88)^{2}$ & 222 & $1.13(0.48-2.64)^{2}$ & 705 & $0.90(0.27-3.02)^{2}$ & 825 & $0.85(0.30-2.52)^{2}$ \\
\hline$\leq 44$ years & 17 & 1 & 49 & 1 & 90 & 1 & 58 & 1 \\
\hline $45-49$ & 18 & $0.59(0.28-1.62)$ & 38 & $2.73(0.70-9.98)$ & 112 & $0.31(0.08-1.18)$ & - & NA \\
\hline $50 \leq$ & 18 & $0.13(0.04-0.51)$ & 44 & $0.72(0.30-2.13)$ & 161 & $0.17(0.05-0.61)$ & & \\
\hline $\mathrm{p}$-trend & & $<0.001$ & & 0.05 & & 0.02 & & \\
\hline \multicolumn{9}{|l|}{$\begin{array}{l}\text { Estrogen exposure } \\
\text { periods }^{3}\end{array}$} \\
\hline$<25$ years & 125 & 1 & 162 & 1 & 337 & 1 & 802 & 1 \\
\hline $25-29$ & 48 & $0.31(0.11-0.85)$ & 119 & $0.78(0.41-1.50)$ & 235 & $0.12(0.03-0.37)$ & 71 & $0.41(0.17-1.00)$ \\
\hline $30 \leq$ & 42 & $0.06(0.02-0.17)^{2}$ & 72 & $0.32(0.11-0.998)^{2}$ & 496 & $0.10(0.04-0.25)^{2}$ & 10 & $7.69(1.96-25.01)^{2}$ \\
\hline & & $<0.001$ & & 0.02 & & $<0.001$ & & $<0.001$ \\
\hline
\end{tabular}

N number, HR hazard ratio, CI confidence interval, NA not available

${ }^{1}$ Adjusted for all listed variables in the table, age at menarche, contraceptive use, number of parity, current drinking status, and birth cohort

${ }^{2}$ Statistically significant heterogeneity among HRs $(95 \%$ CIs) from 4 groups ( $p=0.047$ for age at menarche $\leq 14$ years; $p<0.001$ for premenopause; $p<0.001$ for estrogen exposure periods $\geq 30$ years)

${ }^{3}$ For menopausal women, subtracting the age at menarche from the age at menopause, and for pre-menopausal females, subtracting the age at menarche from the current age

A

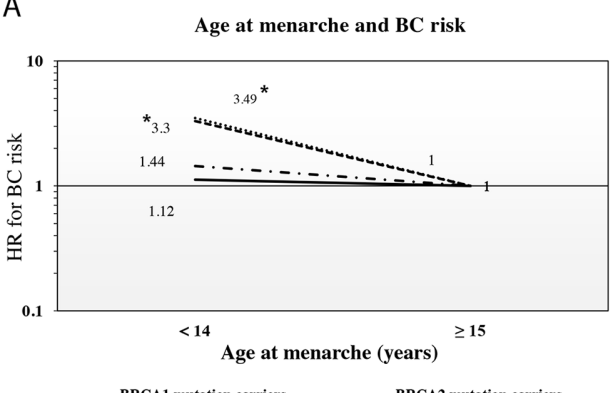

-.- BRCA1 mutation carriers $\quad$........ BRCA2 mutation carriers

C Number of parity and $\mathrm{BC}$ risk

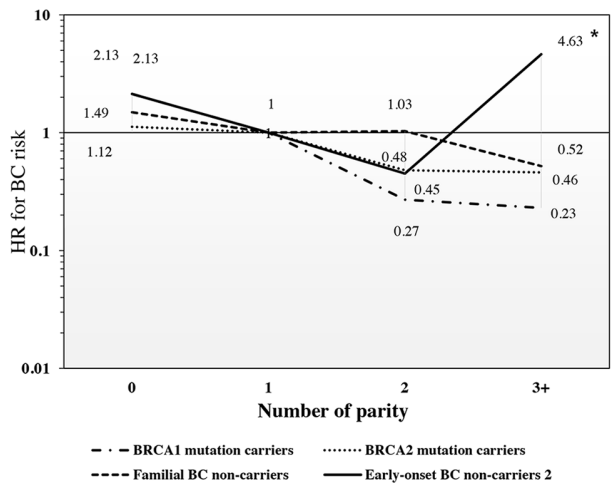

B

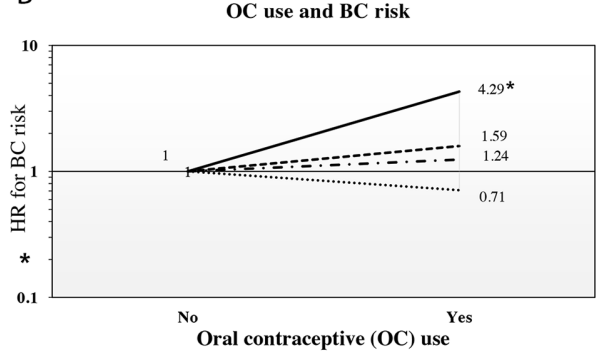

- - - BRCA1 mutation carriers $\quad \cdots \cdots \cdot \cdot$ BRCA2 mutation carriers

---- Familial BC non-carriers _ Early-onset BC non-carriers 2

D

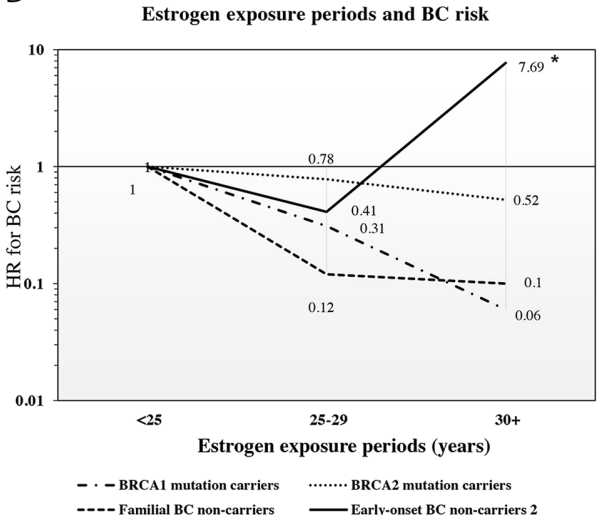

Figure 1: Heterogeneous variation in four HRs $(95 \% \mathrm{CIs})$ for the risk of breast cancer in relation to age at menarche, oral contraceptive use, number of parity, and estrogen exposure periods. (A) Age at menarche and breast cancer risk (B) Oral contraceptive use and breast cancer risk (C) Number of parity and breast cancer risk. (D) Estrogen exposure periods and breast cancer risk. 
inversely associated with high-risk women, such as $B R C A$ mutation carriers and non-carriers with $\mathrm{FH}$, compared with the direction in the general population because high-risk women may develop BC at an early age. The decreased association between late age at menopause ( $\geq 50$ years) and $\mathrm{BC}$ risk or no association in BRCA1/2 mutation carriers and non-carriers with $\mathrm{FH}$ were reported $[10,32]$, because hereditary or familial $\mathrm{BC}$ develops earlier than in the general population $[10,33]$. In our study participants, $>80 \%$ of $\mathrm{BC}$ patients with $B R C A 1$ mutation were $<50$ years old, and few population-based studies regarding the effects of menopause in young age groups are available, with different results compared to those in the general population.

This study had several limitations. First, the KOHBRA study population was selected based on possible hereditary traits for BC from genetic cancer clinics [34]. Effects of selection bias were still present even after minimizing them through a weighted cohort analysis to adjust for the over-representation of the affected cases [35]. Second, family members' participation in the study would be affected by the probands' decisions to inform and recommend genetic mutation tests because the controls were selected from the family members of $\mathrm{BC}$ patients who are $B R C A 1$ or $B R C A 2$ carriers. Another potential limitation was that when the duration of estrogen exposure period was calculated, parity, breastfeeding, and duration of OC use or hormonal replacement therapy were not considered [10].

Despite these limitations, the study had several strengths. Although several studies and meta-analyses existed on the associations between reproductive factors and $\mathrm{BC}$ risk in $B R C A 1 / 2$ mutation carriers, all studies investigated the Caucasians and no results were reported for Asian $B R C A 1 / 2$ mutation carriers until now. Indeed, to the best of our knowledge, this is the only Asian study in the literature. Although most previous studies focused on only BRCA1/2 mutation carriers, this study targeted not only mutation carriers but also high-risk non-carriers. BRCA1/2 mutation carriers, non-carriers with $\mathrm{FH}$ of $\mathrm{BC}$, and non-carriers with early-onset BC were separately evaluated, and the association between the four groups were heterogeneous.

Our results indicate that reproductive factors as risk modifiers are heterogeneously associated with $\mathrm{BC}$ risk among these highly susceptible women, such as $B R C A 1 / 2$ mutation carriers, non-carriers with $\mathrm{FH}$, and non-carriers with early-onset BC. These results are somewhat different from those in the general population. Different directions in the associations compared with the general population should be considered in the management of genetically and highly susceptible women.

\section{MATERIALS AND METHODS}

\section{Study population}

The KOHBRA study is a multicenter cohort study consisting of hereditary high-risk BC patients and family members of $\mathrm{BC}$ patients with $B R C A 1 / 2$ mutation. Hereditary high-risk $\mathrm{BC}$ patients were defined as $\mathrm{BC}$ patients with $\mathrm{FH}$ of breast or ovarian cancers, male $\mathrm{BC}$ patients, female $\mathrm{BC}$ patients aged $\leq 40$ years at diagnosis, bilateral $\mathrm{BC}$ patients, or $\mathrm{BC}$ patients with other organ cancers. All patients were tested for $B R C A 1 / 2$ genetic mutations. BRCA1/2 mutation testing was conducted using fluorescence-based conformation-sensitive gel electrophoresis, denaturing high-performance liquid chromatography, and direct sequencing in four DNA testing laboratories certified annually by the Korean Institute of Genetic Testing Evaluation. Pathogenic mutation was defined as a protein-truncating mutation and a missense mutation with confirmed association with the disease [34]. If a BC patient had a mutation, relatives aged $\geq 20$ years were asked to participate in the study and received test for family-specific $B R C A 1 / 2$ mutation. All participants provided written informed consent and asked to complete structured questionnaires via a personal interview, including their general characteristics, past medical history, FH of malignancies, dietary and physical activities, and reproductive factors. The institutional review board of each participating center approved this study design (IRB \#B-0707-047-005). Details of the study have been described fully elsewhere [34].

Of the 2,858 participants recruited from 2007 to 2014 , female participants $(n=2,684)$ were considered in the analysis after excluding male $\mathrm{BC}$ patients and male family members. After excluding six carriers with both BRCA1 and BRCA2 mutations, 222 BRCA1 and 359 $B R C A 2$ mutation carriers were included. Of the 2,097 non-carriers of $B R C A 1 / 2$ mutation, $882 \mathrm{BC}$ patients with $\mathrm{FH}$ of $\mathrm{BC}$ in the first- and second-degree relatives, 795 $\mathrm{BC}$ patients aged $\leq 40$ years at diagnosis, and 201 controls were included. Appendix Figure 1 describes the details of the selection process of the participants.

\section{Definitions}

$B R C A 1$ or BRCA2 mutation carriers were defined as women with protein-truncating mutation or a missense mutation with confirmed association with the disease within the BRCA1 or BRCA2 gene. Non-carriers with FH of $\mathrm{BC}$ were defined as women with $\mathrm{FH}$ of $\mathrm{BC}$ in first- and second-degree relatives but without $B R C A 1 / 2$ pathogenic mutation. Non-carriers with early-onset BC were defined as those who were diagnosed with $\mathrm{BC}$ at the age of $\leq 40$ years but without $B R C A 1 / 2$ pathogenic mutation. Controls for non-carriers were relatives of $\mathrm{BC}$ patients with $B R C A 1 / 2$ mutation and found to be non-carriers after the family-specific $B R C A 1 / 2$ mutation test. Thus, all noncarrier controls were compared with non-carrier patients with $\mathrm{FH}$ of $\mathrm{BC}$. Among them, those aged $\leq 40$ years at recruitment were compared to non-carriers with earlyonset BC (Appendix Figure 1).

As reproductive factors, we considered age at menarche ( $\leq 14$ years, $\geq 15$ years), OC use (never used, 
ever used), number of parity (nulliparous, 1, 2, $3 \leq$ ), age at FFTP ( $\leq 23,24-29, \geq 30$ years), and age at menopause (premenopause, $\leq 44,45-49, \geq 50$ years). Estrogen exposure period was calculated by subtracting the age at menarche from the age at menopause for menopausal women, and subtracting the age at menarche from the current age for pre-menopausal women.

\section{Statistical analysis}

The $t$-test or chi-square test was used to compare the differences in the distribution of selected characteristics between those affected with $\mathrm{BC}$ and controls. To assess the association between the reproductive factors and BC risk, the weighted multivariate Cox proportional hazard regression model was used to retrospectively analyze the data based on the factors modifying the disease risks in carriers of highly penetrant genes to provide unbiased disease risks [35]. Weights were assigned based on the affected status, age, and $B R C A 1 / 2$ gene mutation, considering the age-specific population incidence and $\mathrm{HR}$ of $\mathrm{BC}$ for $B R C A 1 / 2$ gene mutation carriers in the Korean population [36], and the total follow-up period in affected and unaffected subjects as external rates. For non-carriers, weights were also assigned (Appendix Table 1). These weights have been adjusted for ascertainment bias caused by over-sampling of affected cases because the recruitment of participants was via the genetic clinics [35].

The HRs and 95\% CIs, adjusted for family clustering and covariates, were used to determine the associations between reproductive factors and risk of BC in the four groups. To estimate the time to diagnosis, the follow-up started at birth, and subjects were censored at the age during interview and $\mathrm{BC}$ diagnosis for the controls and BC patients, respectively. The Cochran's Q test was used to determine the heterogeneity across the HRs (95\% CIs) between the four groups [37]. All statistical analyses were conducted using the SAS software (ver. 9.1; SAS Institute, Cary, NC, USA) and Stata/SE (ver. 12.0; LP StataCorp, College Station, TX, USA).

\section{Abbreviations}

$$
\begin{aligned}
& \text { BC, breast cancer } \\
& \text { CI, confidence interval } \\
& \text { FH, family history } \\
& \text { FFTP, first full-term pregnancy } \\
& \text { HR, hazard ratio } \\
& \text { LEEP, longer estrogen exposure periods } \\
& \text { OC, oral contraceptive }
\end{aligned}
$$

\section{ACKNOWLEDGMENTS AND FUNDING}

This study was supported by a grant from the National R\&D Program for Cancer Control, Ministry of Health \& Welfare, Republic of Korea (\#1020350 and \#1420190), a Grant-in-Aid for Cancer Research and
Control from the National Cancer Center of Korea (\# 1710171), Basic Science Research Program through the National Research Foundation of Korea (NRF) funded by the Ministry of Science, ICT and Future Planning (NRF2016R1C1B1013621), and a grant of the Korea Health Technology R\&D Project through the Korea Health Industry Development Institute (KHIDI), funded by the Ministry of Health \& Welfare, Republic of Korea (grant number: HI16C1127).

We thank all investigators of the KOHBRA study : Beom Seok Kwak, Byeong-Woo Park, Byung Ho Son, Byung-In Moon, Cha Kyong Yom, Chan Heun Park, Chan Seok Yoon, Chang Hyun Lee, Dae Sung Yoon, DongYoung Noh, Doo Ho Choi, Eundeok Chang, Eun-Kyu Kim, Eunyoung Kang, Hae Kyung Lee, Hai-Lin Park, Hyde Lee, Hyeong-Gon Moon, Hyun-Ah Kim, Il-Kyun Lee, Jeong Eon Lee, Jihyoun Lee, Jong Won Lee, Jong-Han Yu, Joon Jeong, Jung Han Yoon, Jung-Hyun Yang, Keumhee Kwak, Ki-Tae Hwang, Ku Sang Kim, Lee Su Kim, Min Hee Hur, Min Ho Park, Min Hyuk Lee, Myung Chul Chang, Nam Sun Paik, Sang Ah Han, Sang Seol Jung, Sang Uk Woo, Se Jeong Oh, Sehwan Han, Sei Joong Kim, Sei-Hyun Ahn, Seok-Jin Nam, Seung Sang Ko, Sung Hoo Jung, Sung Soo Kang, Sung Yong Kim, Sung-Won Kim, Tae Hyun Kim, Tae Wan Won, Tae Woo Kang, Wonshik Han, Woo-Chul Noh, Yong Lai Park, Yongsik Jung, Young Jin Suh, Young Tae Bae, Young Up Cho, Young-Ik Hong, Sue K. Park, Yoon Joo Jung, Su Yun Choi, Young Bum Yoo, Soo-Jung Lee.

\section{COMPETING INTERESTS}

The authors state that they have no competing interests.

\section{REFERENCES}

1. O'Donovan PJ, Livingston DM. BRCA1 and BRCA2: breast/ovarian cancer susceptibility gene products and participants in DNA double-strand break repair. Carcinogenesis. 2010; 31: 961-7. https://doi.org/10.1093/ carcin/bgq069.

2. Kennedy RD, Quinn JE, Johnston PG, Harkin DP. BRCA1: mechanisms of inactivation and implications for management of patients. Lancet. 2002; 360: 1007-14. https://doi.org/10.1016/S0140-6736(02)11087-7.

3. Kelsey JL, Gammon MD, John EM. Reproductive factors and breast cancer. Epidemiol Rev. 1993; 15: 36-47.

4. Key TJ, Verkasalo PK, Banks E. Epidemiology of breast cancer. Lancet Oncol. 2001; 2: 133-40. https://doi.org/10.1016/ S1470-2045(00)00254-0.

5. Razandi M, Pedram A, Rosen EM, Levin ER. BRCA1 inhibits membrane estrogen and growth factor receptor signaling to cell proliferation in breast cancer. Mol Cell Biol. 2004; 24: 5900-13. https://doi.org/10.1128/ mcb.24.13.5900-5913.2004. 
6. Poumpouridou N, Kroupis C. Hereditary breast cancer: beyond BRCA genetic analysis; PALB2 emerges. Clin Chem Lab Med. 2012; 50: 423-34. https://doi.org/10.1515/cclm-2011-0840.

7. Frank TS, Deffenbaugh AM, Reid JE, Hulick M, Ward BE, Lingenfelter B, Gumpper KL, Scholl T, Tavtigian SV, Pruss DR, Critchfield GC. Clinical characteristics of individuals with germline mutations in BRCA1 and BRCA2: analysis of 10,000 individuals. J Clin Oncol. 2002; 20: 1480-90.

8. Andrieu N, Goldgar DE, Easton DF, Rookus M, Brohet R, Antoniou AC, Peock S, Evans G, Eccles D, Douglas F, Nogues C, Gauthier-Villars M, Chompret A, et al. Pregnancies, breast-feeding, and breast cancer risk in the International BRCA1/2 Carrier Cohort Study (IBCCS). J Natl Cancer Inst. 2006; 98: 535-44. https://doi.org/10.1093/ jnci/djj132.

9. Antoniou AC, Shenton A, Maher ER, Watson E, Woodward E, Lalloo F, Easton DF, Evans DG. Parity and breast cancer risk among BRCA1 and BRCA2 mutation carriers. Breast Cancer Res. 2006; 8: R72. https://doi.org/10.1186/bcr1630.

10. Chang-Claude J, Andrieu N, Rookus M, Brohet R, Antoniou AC, Peock S, Davidson R, Izatt L, Cole T, Nogues C, Luporsi E, Huiart L, Hoogerbrugge N, et al. Age at menarche and menopause and breast cancer risk in the International BRCA1/2 Carrier Cohort Study. Cancer Epidemiol Biomarkers Prev. 2007; 16: 740-6. https://doi. org/10.1158/1055-9965.EPI-06-0829.

11. Cullinane CA, Lubinski J, Neuhausen SL, Ghadirian P, Lynch HT, Isaacs C, Weber B, Moller P, Offit K, KimSing C, Friedman E, Randall S, Pasini B, et al. Effect of pregnancy as a risk factor for breast cancer in BRCA1/ BRCA2 mutation carriers. Int J Cancer. 2005; 117: 988-91. https://doi.org/10.1002/ijc.21273.

12. Gronwald J, Byrski T, Huzarski T, Cybulski C, Sun P, Tulman A, Narod SA, Lubinski J. Influence of selected lifestyle factors on breast and ovarian cancer risk in BRCA1 mutation carriers from Poland. Breast Cancer Res Treat. 2006; 95: 105-9. https://doi.org/10.1007/ s10549-005-9051-5.

13. Kotsopoulos J, Lubinski J, Lynch HT, Klijn J, Ghadirian P, Neuhausen SL, Kim-Sing C, Foulkes WD, Moller P, Isaacs C, Domchek S, Randall S, Offit K, et al. Age at first birth and the risk of breast cancer in BRCA1 and BRCA2 mutation carriers. Breast Cancer Res Treat. 2007; 105: 2218. https://doi.org/10.1007/s10549-006-9441-3.

14. Milne RL, Osorio A, Ramon y Cajal T, Baiget M, Lasa A, Diaz-Rubio E, de la Hoya M, Caldes T, Teule A, Lazaro C, Blanco I, Balmana J, Sanchez-Olle G, et al. Parity and the risk of breast and ovarian cancer in BRCA1 and BRCA2 mutation carriers. Breast Cancer Res Treat. 2010; 119: 22132. https://doi.org/10.1007/s10549-009-0394-1.

15. Rebbeck TR, Wang Y, Kantoff PW, Krithivas K, Neuhausen SL, Godwin AK, Daly MB, Narod SA, Brunet JS, Vesprini D, Garber JE, Lynch HT, Weber BL, et al. Modification of BRCA1and BRCA2-associated breast cancer risk by AIB1 genotype and reproductive history. Cancer Res. 2001; 61: 5420-4.
16. Tryggvadottir L, Olafsdottir EJ, Gudlaugsdottir S, Thorlacius S, Jonasson JG, Tulinius H, Eyfjord JE. BRCA2 mutation carriers, reproductive factors and breast cancer risk. Breast Cancer Res. 2003; 5: R121-8. https://doi. org/10.1186/bcr619.

17. Kotsopoulos J, Lubinski J, Lynch HT, Neuhausen SL, Ghadirian P, Isaacs C, Weber B, Kim-Sing C, Foulkes WD, Gershoni-Baruch R, Ainsworth P, Friedman E, Daly $\mathrm{M}$, et al. Age at menarche and the risk of breast cancer in BRCA1 and BRCA2 mutation carriers. Cancer Causes Control. 2005; 16: 667-74. https://doi.org/10.1007/ s10552-005-1724-1.

18. Bernstein L, Teal CR, Joslyn S, Wilson J. Ethnicity-related variation in breast cancer risk factors. Cancer. 2003; 97: 222-9. https://doi.org/10.1002/cncr.11014.

19. Park B, Ma SH, Shin A, Chang MC, Choi JY, Kim S, Han W, Noh DY, Ahn SH, Kang D, Yoo KY, Park SK. Korean risk assessment model for breast cancer risk prediction. PLoS One. 2013; 8: e76736.

20. Kang E, Seong MW, Park SK, Lee JW, Lee J, Kim LS, Lee JE, Kim SY, Jeong J, Han SA, Kim SW. The prevalence and spectrum of BRCA1 and BRCA2 mutations in Korean population: recent update of the Korean Hereditary Breast Cancer (KOHBRA) study. Breast Cancer Res Treat. 2015; 151: 157-68. https://doi.org/10.1007/s10549-015-3377-4.

21. Anderson WF, Matsuno RK, Sherman ME, Lissowska J, Gail MH, Brinton LA, Yang XR, Peplonska B, Chen BE, Rosenberg PS. Estimating age-specific breast cancer risks: a descriptive tool to identify age interactions. Cancer Causes \& Control. 2007; 18: 439-47.

22. Palmer JR, Wise LA, Horton NJ, Adams-Campbell LL, Rosenberg L. Dual effect of parity on breast cancer risk in African-American women. J Natl Cancer Inst. 2003; 95: 478-83.

23. Liu Q, Wuu J, Lambe M, Hsieh SF, Ekbom A, Hsieh CC. Transient increase in breast cancer risk after giving birth: postpartum period with the highest risk (Sweden). Cancer Causes \& Control. 2002; 13: 299-305.

24. Lambe M, Hsieh CC, Trichopoulos D, Ekbom A, Pavia M, Adami HO. Transient increase in the risk of breast cancer after giving birth. New England Journal of Medicine. 1994; 331: 5-9.

25. Moorman PG, Iversen ES, Marcom PK, Marks JR, Wang F, Lee E, Ursin G, Rebbeck TR, Domchek SM, Arun B, Susswein L, Isaacs C, Garber JE, et al. Evaluation of established breast cancer risk factors as modifiers of BRCA1 or BRCA2: a multi-center case-only analysis. Breast Cancer Res Treat. 2010; 124: 441-51. https://doi. org/10.1007/s10549-010-0842-y.

26. Russo J, Russo IH. Cellular basis of breast cancer susceptibility. Oncol Res. 1999; 11: 169-78.

27. Collaborative Group on Hormonal Factors in Breast Cancer. Breast cancer and hormonal contraceptives: collaborative reanalysis of individual data on 53297 women with breast cancer and 100239 women without breast cancer from 54 epidemiological studies. Lancet. 1996; 347: 1713-27. 
28. Friebel TM, Domchek SM, Rebbeck TR. Modifiers of cancer risk in BRCA1 and BRCA2 mutation carriers: systematic review and meta-analysis. J Natl Cancer Inst. 2014; 106: https://doi.org/10.1093/jnci/dju091.

29. Pan H, He Z, Ling L, Ding Q, Chen L, Zha X, Zhou W, Liu X, Wang S. Reproductive factors and breast cancer risk among BRCA1 or BRCA2 mutation carriers: results from ten studies. Cancer Epidemiol. 2014; 38: 1-8. https://doi. org/10.1016/j.canep.2013.11.004.

30. Karapanou O, Papadimitriou A. Determinants of menarche. Reprod Biol Endocrinol. 2010; 8: 115. https://doi. org/10.1186/1477-7827-8-115.

31. van den Berg SM, Boomsma DI. The familial clustering of age at menarche in extended twin families. Behav Genet. 2007; 37: 661-7. https://doi.org/10.1007/s10519-007-9161-4.

32. Lee E, Ma H, McKean-Cowdin R, Van Den Berg D, Bernstein L, Henderson BE, Ursin G. Effect of reproductive factors and oral contraceptives on breast cancer risk in BRCA1/2 mutation carriers and noncarriers: results from a population-based study. Cancer Epidemiol Biomarkers Prev. 2008; 17: 3170-8. https://doi.org/10.1158/1055-9965. epi-08-0396.
33. Pruthi S, Gostout BS, Lindor NM. Identification and Management of Women With BRCA Mutations or Hereditary Predisposition for Breast and Ovarian Cancer. Mayo Clin Proc. 2010; 85: 1111-20. https://doi.org/10.4065/ mcp.2010.0414.

34. Han SA, Park SK, Ahn SH, Lee MH, Noh DY, Kim LS, Noh WC, Jung Y, Kim KS, Kim SW. The Korean Hereditary Breast Cancer (KOHBRA) study: protocols and interim report. Clin Oncol (R Coll Radiol). 2011; 23: 43441. https://doi.org/10.1016/j.clon.2010.11.007.

35. Antoniou AC, Goldgar DE, Andrieu N, Chang-Claude J, Brohet R, Rookus MA, Easton DF. A weighted cohort approach for analysing factors modifying disease risks in carriers of high-risk susceptibility genes. Genet Epidemiol. 2005; 29: 1-11. https://doi.org/10.1002/gepi.20074.

36. Park B, Dowty JG, Ahn C, Win AK, Kim SW, Lee MH, Lee JW, Kang E, Hopper JL, Park SK. Breast cancer risk for Korean women with germline mutations in BRCA1 and BRCA2. Breast cancer research and treatment. 2015; 152: 659-65.

37. Higgins JP, Thompson SG, Deeks JJ, Altman DG. Measuring inconsistency in meta-analyses. BMJ. 2003; 327: 557. 